\title{
Factor XII 46C $\rightarrow$ T Gene Polymorphism in Chilean Subjects with Coronary Artery Disease and Controls
}

\author{
José Caamaño ${ }^{a}$ briscilla C. Jaramillo ${ }^{a}$ Cecilia Lanas $^{b}$ Fernando Lanas ${ }^{b}$ \\ Luis A. Salazar ${ }^{\text {a }}$ \\ aLaboratorio de Biología Molecular y Farmacogenética, Departamento de Ciencias Básicas, and \\ ${ }^{\text {b}}$ Departamento de Medicina Interna, Facultad de Medicina, Universidad de La Frontera, Temuco, Chile
}

\section{Key Words}

F12 gene $\cdot$ Coagulation factors $\cdot$ Coronary artery disease . C46T polymorphism

\begin{abstract}
Objective: To investigate the possible association between factor XII (F12) gene variant and the presence of coronary artery disease (CAD) in Chilean subjects. Methods: A total of 112 unrelated patients with a diagnosis of CAD confirmed by angiography (33-74 years old) and 107 healthy controls (3068 years old) were included in this study. PCR-RFLP was used to evaluate the $46 \mathrm{C} \rightarrow$ T polymorphism of the $F 12$ gene. $R$ esults: The genotype distribution for the $46 \mathrm{C} \rightarrow \mathrm{T}$ variant of the $F 12$ gene in CAD patients (CC: $41 \%, C T: 39 \%$, TT: $20 \%$ ) and controls (CC: $38 \%$, CT: $48 \%$, TT: $14 \%$ ) was comparable ( $p=$ $0.365)$. Similarly, the allelic frequency was equivalent ( $p=$ 0.833 ). The odds ratio for $C A D$ associated with the mutated $46 \mathrm{~T}$ allele was $1.06(95 \% \mathrm{Cl}=0.72-1.56)$ confirming the $\mathrm{ab}$ sence of an association. Conclusion: This study showed that the $F 1246 C \rightarrow$ T gene polymorphism is not related to CAD in the studied population. However, this study is limited by its sample size and the use of controls not matched by age and sex.

Copyright $\odot 2009$ S. Karger AG, Basel
\end{abstract}

\section{KARGER}

Fax +41613061234

E-Mail karger@karger.ch

www.karger.com (c) 2009 S. Karger AG, Basel

1011-7571/09/0182-0137\$26.00/0

Accessible online at:

www.karger.com/mpp

\section{Introduction}

Coronary artery disease (CAD) is the main cause of mortality in Chile [1]. Although there is substantial evidence that genetic factors contribute to CAD [2], a small number of such studies have been carried out in Chile [ 3 , 4]. To date different genes have been related to CAD, among them, the genes encoding the coagulation factors [5-7].

Common genetic variants at factors I, II, V, VII and XIII have been associated with cardiovascular diseases in several populations $[8,9]$. In addition, a common polymorphism at the factor XII (F12) gene, 46C $\rightarrow \mathrm{T}$ (rs1801020), has been related to CAD risk [10-12]. Santamaría et al. [11, 12] reported that the homozygosity for the $\mathrm{T}$ allele of the $46 \mathrm{C} \rightarrow \mathrm{T}$ polymorphism of the F12 gene increased the risk of ischemic stroke and acute CAD. Similarly, the WOSCOPS study showed that individuals carrying the mutated $\mathrm{T}$ allele have a high risk of developing acute coronary disease [10]. In addition, Tirado et al. [13] showed that the $46 \mathrm{C} \rightarrow \mathrm{T}$ polymorphism is an independent risk factor for venous thrombosis.

However, these findings are not in accordance with previous observations of Endler et al. [14, 15], who suggested that the presence of the $\mathrm{T}$ allele for the $46 \mathrm{C} \rightarrow \mathrm{T}$

Prof. Luis A. Salazar, PhD

Facultad de Medicina, Universidad de La Frontera

Av. Francisco Salazar 01145, Casilla 54-D

Temuco (Chile)

Tel. +56 45325 218, Fax +56 45325 236, E-Mail lsalazar@ufro.cl 
polymorphism at F12 could represent a protective factor for CAD considering that this genetic variation is associated with decreased F12 activity [15]. In view of these contradictory results, the aim of the present study was to evaluate the possible association between the $46 \mathrm{C} \rightarrow \mathrm{T}$ gene polymorphism of the $F 12$ gene and CAD in Chilean subjects.

\section{Subjects and Methods}

Subjects

The F12 polymorphism was analyzed in 112 unrelated Chilean patients (83 men and 29 women), ages 33-74 years, with a diagnosis of CAD documented by angiography (coronary artery stenosis $>70 \%$ ), admitted to the Cardiology Service of the Hernán Henríquez Hospital of Temuco city, Chile. For the control group consisting of 107 unrelated individuals (61 men and 46 women), ages 30-68 years, from Temuco city, we used a structured questionnaire to identify disease-free controls and to exclude subjects who were suspected of having any form of vascular disease. Controls with a familial history of CAD, determined by interviewing, were also excluded from the study.

Demographic data and history of hypertension, diabetes mellitus, cigarette smoking, and hypercholesterolemia were assessed in each subject. In both groups, there was no preselection of serum lipid levels. Subjects with a history of diabetes or basal glyce$\mathrm{mia} \geq 126 \mathrm{mg} / \mathrm{dl}$ were defined as diabetic. The study protocol was approved by the ethics committee of our university, and all subjects gave written informed consents.

\section{Serum Measurements}

Biochemical measurements were determined from blood samples collected by venipuncture after overnight $(>12 \mathrm{~h})$ fast. Previously described enzymatic methods [3] were used to determine the levels of serum glucose, uric acid, triglycerides, total cholesterol and high-density lipoprotein cholesterol (HDL-C). Lowdensity lipoprotein cholesterol (LDL-C) was calculated using the Friedewald equation when the triglyceride concentrations did not exceed $400 \mathrm{mg} / \mathrm{dl}$.

\section{DNA Analysis}

Genomic DNA was extracted from blood leukocytes by a salting-out method optimized by Salazar et al. [16]. The 46C $\rightarrow \mathrm{T}$ polymorphism of the F12 gene was detected using PCR followed by enzymatic restriction according to conditions described by Zito et al. [17]. The correct assessment of genotypes for the 46C $\rightarrow$ T polymorphism of the F12 gene was evaluated using a homozygous sample for the restriction site as a positive control. In addition, all gels were reread blindly by two persons (J.C. and L.A.S.) without any change, and $10 \%$ of the analyses were repeated randomly.

\section{Statistical Analysis}

Statistical analysis was carried out using the Sigma Stat Software, ver. 2.0 (Jandel Sci., San Rafael, Calif., USA). Data are presented as mean \pm SD. The Student $t$ test or one-way ANOVA was used to evaluate differences between the means of continuous variables. The allelic frequencies and genotype distribution were estimated by gene counting. Multiple comparisons were performed by the Tukey method. Differences between noncontinuous variables, and Hardy-Weinberg equilibrium were tested by $\chi^{2}$ analysis. ORs and their 95\% CIs associated with the mutated 46T allele were also calculated. Statistical significance was set at $\mathrm{p}<$ 0.05 .

\section{Results}

\section{Clinical Variables}

The clinical, anthropometric and laboratory characteristics of the study subjects are given in table 1 . The CAD subjects had an elevated body mass index (BMI) and a higher prevalence of traditional risk factors for $\mathrm{CAD}$, including smoking, diabetes, hypertension, hypercholesterolemia and familial history of CAD ( $<<0.001)$. The baseline serum concentrations of triglycerides, glucose and uric acid were higher in CAD patients than controls. In addition, CAD subjects presented lower HDL-C levels $(p<0.001)$. There was no significant difference in the mean serum concentrations of total cholesterol and LDL-C between the CAD and control groups ( $p=0.053$ ). Similarly, there was no significant difference in the mean values of diastolic and systolic blood pressures between CAD and control subjects ( $\mathrm{p}=0.156$ and 0.235 , respectively).

\section{Allele Frequencies}

The genotype distribution and the relative allele frequency of the $46 \mathrm{C} \rightarrow$ T polymorphism of the F12 gene in CAD patients and controls are given in table 2. For both groups, CAD and control subjects, the distribution of genotypes was as expected from the Hardy-Weinberg equilibrium (CAD patients: $\chi^{2}=3.48, \mathrm{p}=\mathrm{NS}$; controls: $\left.\chi^{2}=0.018, p=N S\right)$. The genotype distribution for the $46 \mathrm{C} \rightarrow \mathrm{T}$ polymorphism in CAD patients and controls was similar $(\mathrm{p}=0.365)$. Similarly, the allelic frequency was equivalent in both groups $(\mathrm{p}=0.833)$. Moreover, the OR for CAD related to the 46T allele was $1.06(95 \%$ $\mathrm{CI}=0.72-1.56)$ confirming the absence of an association. A possible association between the $46 \mathrm{C} \rightarrow \mathrm{T}$ polymorphism and traditional risk factors for CAD was also explored. We observed that the individuals carrying the TT genotype exhibited a higher BMI and higher levels of uric acid when compared to other genotypes (table 3). A comparison of various studies involving mostly Caucasians with our study (Amerindians) is given in table 4. 
Table 1. Clinical and demographic characteristics of the Chilean subjects with CAD $(\mathrm{n}=112)$ and controls $(\mathrm{n}=107)$

\begin{tabular}{lccr}
\hline & CAD & Controls & \multicolumn{1}{c}{$\mathrm{p}$} \\
\hline Age, years & $59.7 \pm 9.9$ & $41.8 \pm 9.4$ & $<0.001$ \\
Male, \% & 74 & 56 & 0.007 \\
Diabetes, \% & 39 & 5 & $<0.001$ \\
SBP, mm Hg & $129 \pm 21$ & $125 \pm 21$ & 0.235 \\
DBP, mm Hg & $77 \pm 11$ & $80 \pm 16$ & 0.156 \\
BMI & $27.6 \pm 4.9$ & $25.5 \pm 3.3$ & $<0.001$ \\
Smoking, \% & 64 & 41 & 0.001 \\
Hypercholesterolemia, \% & 80 & 20 & $<0.001$ \\
Hypertension, \% & 79 & 26 & $<0.001$ \\
Angina, \% & 77 & 0 & $<0.001$ \\
AMI, \% & 64 & 0 & $<0.001$ \\
Family history of CAD, \% & 36 & 0 & $<0.001$ \\
Diseased vessels, \% & & & \\
$\quad$ Single vessel & 32.2 & 0 & - \\
$\quad$ Double vessel & 27.6 & 0 & - \\
$\quad$ Triple vessel & 40.2 & 0 & - \\
Total cholesterol, mg/dl & $184 \pm 54$ & $198 \pm 53$ & 0.053 \\
LDL-C, mg/dl & $116 \pm 37$ & $115 \pm 42$ & 0.913 \\
HDL-C, mg/dl & $32 \pm 8$ & $52 \pm 12$ & $<0.001$ \\
Triglycerides, mg/dl & $182 \pm 193$ & $136 \pm 96$ & 0.029 \\
Fasting glucose, mg/dl & $112 \pm 42$ & $96 \pm 40$ & 0.005 \\
Uric acid, mg/dl & $5.6 \pm 1.6$ & $4.5 \pm 1.5$ & $<0.001$ \\
\hline
\end{tabular}

$\mathrm{BMI}=$ Body mass index; $\mathrm{DBP}=$ diastolic blood pressure; $\mathrm{SBP}=$ systolic blood pressure; $\mathrm{AMI}=$ acute myocardial infarction . $p$ values from Student's t test or $\chi^{2}$ test.

Table 2. Genotype distribution and relative allele frequencies of the $46 \mathrm{C} \rightarrow \mathrm{T}$ polymorphism of the $\mathrm{F} 12$ gene in Chilean subjects with CAD $(\mathrm{n}=112)$ and controls $(\mathrm{n}=107)$

\begin{tabular}{lllllll}
\hline & \multicolumn{2}{l}{ Genotype } & & & \multicolumn{2}{l}{ Allele } \\
\cline { 2 - 3 } \cline { 5 - 7 } & CC & CT & TT & & C & T \\
\hline CAD & $46(41 \%)$ & $44(39 \%)$ & $22(20 \%)$ & & 0.607 & 0.393 \\
Controls & $41(38 \%)$ & $51(48 \%)$ & $15(14 \%)$ & & 0.622 & 0.378 \\
& $\chi^{2}=2.01 ;$ & & & & $\chi^{2}=0.04 ;$ \\
& d.f. $=2 ;$ & & & & d.f. $=1 ;$ \\
& $\mathrm{p}=0.365$ & & & & $\mathrm{p}=0.833$ \\
& & & & & & \\
\hline
\end{tabular}

\section{Discussion}

In several studies [10-14], the association between the $46 \mathrm{C} \rightarrow$ T polymorphism of the F12 gene and cardiovascular diseases has been investigated. However, the results are controversial. In the present study, we have investi-
Table 3. Clinical and demographic characteristics of subjects with $\mathrm{CAD}$ according to the $46 \mathrm{C} \rightarrow \mathrm{T}$ genotypes of the $\mathrm{F} 12$ gene

\begin{tabular}{lcccc}
\hline & $\begin{array}{l}\text { CC } \\
(\mathrm{n}=46)\end{array}$ & $\begin{array}{l}\mathrm{CT} \\
(\mathrm{n}=44)\end{array}$ & $\begin{array}{l}\mathrm{TT} \\
(\mathrm{n}=22)\end{array}$ & $\mathrm{p}$ \\
\hline Age, years & $60 \pm 7$ & $58 \pm 12$ & $63 \pm 12$ & 0.565 \\
Diabetes, \% & 35 & 31 & 25 & 0.732 \\
SBD, mm Hg & $128 \pm 18$ & $128 \pm 18$ & $136 \pm 21$ & 0.341 \\
DBP, mm Hg & $76 \pm 13$ & $77 \pm 9$ & $79 \pm 11$ & 0.570 \\
BMI & $28 \pm 3.9$ & $27.1 \pm 3.7$ & $30.7 \pm 5.9$ & 0.032 \\
Hypercholesterolemia, \% & 70 & 62 & 50 & 0.314 \\
Hypertension, \% & 70 & 58 & 55 & 0.391 \\
Diseased vessels, \% & & & & \\
$\quad$ Single vessel & 26 & 22 & 20 & \\
$\quad$ Double vessel & 15 & 29 & 20 & 0.679 \\
$\quad$ Triple vessel & 35 & 29 & 30 & \\
Total cholesterol, mg/dl & $187 \pm 51$ & $176 \pm 42$ & $196 \pm 78$ & 0.356 \\
LDL-C, mg/dl & $117 \pm 39$ & $115 \pm 36$ & $117 \pm 37$ & 0.968 \\
HDL-C, mg/dl & $33 \pm 8$ & $32 \pm 8$ & $31 \pm 9$ & 0.791 \\
Triglycerides, mg/dl & $193 \pm 157$ & $143 \pm 85$ & $254 \pm 368$ & 0.105 \\
Uric acid, mg/dl & $5.3 \pm 1.4$ & $5.4 \pm 1.8$ & $6.5 \pm 1.4$ & 0.018 \\
\hline
\end{tabular}

DBP $=$ Diastolic blood pressure; $\mathrm{SBP}=$ systolic blood pressure. $p$ values from one-way ANOVA or $\chi^{2}$ test. Comparisons by the Tukey method: BMI, TT vs. CT ( $p=0.025)$, TT vs. CC $(p=0.088)$; uric acid, TT vs. CT ( $\mathrm{p}=0.029)$, TT vs. CC $(\mathrm{p}=0.021)$.

gated, for the first time in Chile, the possible association between the $\mathrm{F} 12$ 46C $\rightarrow$ T polymorphism and CAD.

The observed higher serum levels of triglycerides, glucose and uric acid in CAD subjects compared with controls and the lower HDL-C concentrations con-firmed the well-known associations between traditional risk factors and CAD. However, the concentrations of total cholesterol and LDL-C were similar in CAD subjects and controls probably due to statin therapy in CAD patients.

Our data also showed that the $46 \mathrm{C} \rightarrow \mathrm{T}$ polymorphism of the F12 gene is not associated with CAD in Chilean subjects as the frequency of the $46 \mathrm{~T}$ allele was similar in CAD and control subjects (39.3 vs. 37.8\%). This finding is similar to others [18-21]. Orth et al. [18], in Germany, found no evidence that the $46 \mathrm{C} \rightarrow \mathrm{T}$ polymorphism is associated with CAD or thrombophilia. Likewise, Colhoun et al. [19] failed to establish an association between this polymorphism and coronary artery calcification in diabetic subjects and controls. Kohler et al. [20] did not find an association either between the $46 \mathrm{C} \rightarrow$ T polymorphism and CAD. Recently, Bach et al. [21], in a hospitalbased cohort study that evaluated 2,615 patients undergoing coronary angiography and 572 controls, did not 
Table 4. Comparison of different studies investigating the $46 \mathrm{C} \rightarrow \mathrm{T}$ polymorphism of the F12 gene

\begin{tabular}{|c|c|c|c|c|c|c|}
\hline Reference & Study design & $\begin{array}{l}\text { Cases/ } \\
\text { controls }\end{array}$ & Ethnicity & CVD diagnosis & $\begin{array}{l}\text { Frequency of } 46 \mathrm{~T} \text {, } \\
\text { cases/controls }\end{array}$ & $\begin{array}{l}\text { Association } \\
\text { with CVD }\end{array}$ \\
\hline Zito et al. [10] & case-control $^{1}$ & $441 / 990$ & Caucasian & fatal or non-fatal $\mathrm{MI}^{2}$ & $0.29 / 0.26$ & yes $^{3}$ \\
\hline Santamaría et al. [11] & case-control $^{4}$ & $205 / 231$ & Caucasian & ischemic stroke $e^{5}$ & $0.22 / 0.20$ & yes \\
\hline Santamaría et al. [12] & case-control & $174 / 211$ & Caucasian & acute $\mathrm{CAD}^{6}$ & $0.23 / 0.20$ & yes \\
\hline Endler et al. [14] & case-control & $303 / 325$ & Caucasian & $\mathrm{CAD}^{7}$ & $0.26 / 0.27$ & yes $^{8}$ \\
\hline Kohler et al. [20] & case-control & $266 / 185$ & Caucasian & $\mathrm{CAD}^{9}$ & $0.27 / 0.30$ & no \\
\hline Bach et al. [21] & case-control & $2,043 / 572$ & Caucasian & stable CHD, MI, ACS & $0.25 / 0.23$ & no \\
\hline Roldán et al. [22] & case-control & $281 / 550$ & Caucasian & $\mathrm{MI}^{10}$ & $0.18 / 0.21$ & yes \\
\hline Present study & case-control & $112 / 107$ & Amerindian & $\mathrm{CAD}^{11}$ & $0.39 / 0.38$ & no \\
\hline
\end{tabular}

$\mathrm{CVD}=$ Cardiovascular disease $\mathrm{MI}=$ myocardial infarction; $\mathrm{CHD}=$ coronary heart disease; ACS = acute coronary syndromes.

${ }^{1}$ Matched by age and smoking habit.

${ }^{2}$ Individuals who, during the course of the (average) 4.8- to 5-year follow-up, experienced a definitive or suspect fatal or nonfatal MI, sudden coronary death or required coronary artery bypass graft or angioplasty were defined as cases.

${ }^{3}$ Associated with a high risk of CHD in men with high cholesterol levels.

${ }^{4}$ Matched by age, gender and ethnic origin.

${ }^{5}$ Subjects who had at least 1 episode of ischemic stroke.

${ }^{6}$ Acute CAD was confirmed on the basis of definitive ischemia or necrosis of the myocardium.

${ }^{7}$ CAD with or without ACS.

8 The homozygosity of the T allele in patients with CAD + ACS is a protector factor.

${ }^{9} \mathrm{CAD}$ based on the presence of $\geq 50 \%$ stenosis in a major coronary artery or one of their branches.

${ }^{10}$ Patients with acute MI before 45 years.

${ }^{11} \mathrm{CAD}$ documented by angiography (coronary artery stenosis $>70 \%$ ).

observe any association between F12 genotypes and clinical phenotype of cardiovascular diseases.

However, other studies have shown an association between the $46 \mathrm{C} \rightarrow \mathrm{T}$ polymorphism of the $F 12$ gene and CAD [10-14, 22-25]. Zito et al. [10] observed that this polymorphism is associated with a high risk of coronary disease in men with elevated levels of cholesterol. Roldán et al. [22] observed a synergistic association between hypercholesterolemia and the $46 \mathrm{C} \rightarrow \mathrm{T} F 12$ polymorphism for developing premature myocardial infarction in Spanish subjects.

Soria et al. [23] and Tirado et al. [13] have reported that the $46 \mathrm{C} \rightarrow \mathrm{T}$ polymorphism is a genetic risk factor for thrombotic disease in a Spanish population. Recently, Cochery-Nouvellon et al. [24] observed that the homozygosity for the $46 \mathrm{C} \rightarrow \mathrm{T}$ polymorphism of the $\mathrm{F} 12$ gene is a risk factor for venous thrombosis during the first pregnancy. Reuner et al. [25] have suggested that the $46 \mathrm{C} \rightarrow$ T polymorphism may be a new independent risk factor for cerebral venous thrombosis, and that this genetic variant should be added to the panel of established risk factors. On the contrary, Endler et al. [14] suggested that the presence of the 46T allele protects against the development of acute coronary syndrome in patients with preexisting CAD.
Studies analyzing the possible role of gene variants and their respective gene products in cardiovascular diseases have often produced conflicting results. According to Bach et al. [26], the reasons for these discrepancies include the differences in study design, the definition of inclusion and exclusion criteria and the number and ethnicity of the subjects. The analysis of different studies investigating the association between the $46 \mathrm{C} \rightarrow \mathrm{T}$ polymorphism of the F12 gene and cardiovascular disease (table 4) showed significant differences between the diagnostic criteria and study design. The contradictory results could be explained, at least in part, by undetected ethnic admixture in the cases and/or controls that falsely distorts allele frequencies in some situations. In a recent study [27], a significant interethnic allelic variation for the $46 \mathrm{C} \rightarrow \mathrm{T}$ polymorphism of the $F 12$ gene was described across populations, with a higher allele frequency in African-Americans (46\%) and a minor frequency in Caucasians (22\%) [27]. Gene-gene and gene-environmental interactions could also explain the contradictory results of the association between the $46 \mathrm{C} \rightarrow \mathrm{T}$ polymorphism of the F12 gene and CAD. There exists evidence which emphasizes the importance of these interactions in circulatory disorders [28]. 
In addition, we evaluated possible associations between the F12 46C $\rightarrow$ T polymorphism and traditional risk factors for $\mathrm{CAD}$. We observed that $\mathrm{CAD}$ patients carrying the homozygous TT genotype exhibited a higher BMI and higher serum levels of uric acid. Previous studies $[29,30]$ reported that F12a (activated form of F12) levels were significantly correlated with BMI, age, cholesterol, triglycerides and uric acid levels. Endler et al. [15] and Zito et al. $[10,17]$ reported that the $46 \mathrm{C} \rightarrow \mathrm{T}$ polymorphism is a determinant of F12 activity. In these studies, the $\mathrm{T}$ allele for the $46 \mathrm{C} \rightarrow \mathrm{T}$ polymorphism was associated with lower plasma F12a. The reduced fibrinolysis as a consequence of lower plasma F12a may be the mechanism leading to higher risk of CAD. However, in our study, we did not measure F12 activity. This limitation confines the discussion of our findings.

\section{Conclusion}

The present study suggests that the $46 \mathrm{C} \rightarrow \mathrm{T}$ polymorphism of the F12 gene is not associated with CAD in Chilean individuals. However, this study is restricted by its sample size and the use of controls not matched by age and sex.

\section{Acknowledgements}

This study was supported by grants from Dirección de Investigación y Desarrollo, Universidad de La Frontera, Convenio de Desempeño-I-2008 (L.A.S.). J.C. is the recipient of a fellowship from MIDEPLAN, Chile.

\section{References}

1 Lanas F, Avezum A, Bautista LE, Díaz R, Luna M, Islam S, Yusuf S, INTERHEART Investigators in Latin America: Risk factors for acute myocardial infarction in Latin America: the INTERHEART Latin American study. Circulation 2007;115:1067-1074.

2 Mayer B, Erdmann J, Schunkert H: Genetics and heritability of coronary artery disease and myocardial infarction. Clin Res Cardiol 2007:96:1-7.

3 Jaramillo PC, Muñoz A, Lanas C, Lanas F, Salazar LA: Endothelial nitric oxide synthase G894T gene polymorphism in Chilean subjects with coronary artery disease and controls. Clin Chim Acta 2006;371:102106.

-4 Jaramillo PC, Lanas C, Lanas F, Salazar LA: $-786 \mathrm{~T}>\mathrm{C}$ polymorphism of the endothelial nitric oxide synthase gene in Chilean subjects with coronary artery disease and controls. Clin Chim Acta 2008;387:105-108.

5 Pare G, Serre D, Brisson D, Anand SS, Montpetit A, Tremblay G, Engert JC, Hudson TJ, Gaudet D: Genetic analysis of 103 candidate genes for coronary artery disease and associated phenotypes in a founder population reveals a new association between endothelin1 and high-density lipoprotein cholesterol. Am J Hum Genet 2007;80:673-682.

6 Salazar LA, Hirata MH, Giannini SD, Forti N, Diament J, Lima TM, Hirata RD: Seven DNA polymorphisms at the candidate genes of atherosclerosis in Brazilian women with angiographically documented coronary artery disease. Clin Chim Acta 2000;300:139149.
7 Wu A, Tsongalis G: Correlation of polymorphism to coagulation and biochemical risk factors for cardiovascular diseases. Am J Cardiol 2001;87:1361-1366.

-8 Taymaz H, Erarslan S, Oner ET, Alkan T, Ağirbaşli M, Kirdar B: Sequence variations within the genes related to hemostatic imbalance and their impact on coronary artery disease in Turkish population. Thromb Res 2007; 119:55-62.

$\checkmark 9$ Martinelli N, Trabetti E, Pinotti M, Olivieri O, Sandri M, Friso S, Pizzolo F, Bozzini C, Caruso PP, Cavallari U, Cheng S, Pignatti PF, Bernardi F, Corrocher R, Girelli D: Combined effect of hemostatic gene polymorphisms and the risk of myocardial infarction in patients with advanced coronary atherosclerosis. PLoS ONE 2008;3:e1523.

10 Zito F, Lowe G, Rumley A, McMahon A, Humphries S: Association of the factor XII $46 \mathrm{C}>\mathrm{T}$ polymorphism with risk of coronary heart disease (CHD) in the WOSCOPS study. Atherosclerosis 2002;165:153-158.

11 Santamaría A, Mateo J, Tirado I, Oliver A, Belvís R, Martí-Fábregas J, Felices R, Soria JM, Souto JC, Fontcuberta J: Homozygosity of the $\mathrm{T}$ allele of the $46 \mathrm{C}>\mathrm{T}$ polymorphism in the F12 gene is a risk factor for ischemic stroke in the Spanish population. Stroke 2004;35:1795-1799.

- 12 Santamaría A, Martinez-Rubio A, Mateo J, Tirado I, Soria J, Fontcuberta J: Homozygosity of the $\mathrm{T}$ allele of the $46 \mathrm{C}>\mathrm{T}$ polymorphism in the F12 gene is a risk factor for acute coronary artery disease in the Spanish population. Haematologica 2004;89:878-879.
13 Tirado I, Soria JM, Mateo J, Oliver A, Souto JC, Santamaria A, Felices R, Borrell M, Fontcuberta J: Association after linkage analysis indicates that homozygosity for the $46 \mathrm{C}>\mathrm{T}$ polymorphism in the F12 gene is a genetic risk factor for venous thrombosis. Thromb Haemost 2004;91:899-904.

14 Endler G, Mannhalter C, Sunder-Plassmann H, Lalouschek W, Kapiotis S, Exner M, Jordanova N, Meier S, Kunze F, Wagner O, Huber K: Homozygosity for the $\mathrm{C}>\mathrm{T}$ polymorphism at nucleotide 46 in the 5'untraslated region of the factor XII gene protects from development of acute coronary syndrome. Br J Haematol 2001;115:1007-1009.

-15 Endler G, Exner M, Mannhalter C, Meier S, Ruzicka K, Handler S, Panzer S, Wagner O, Quehenberger P: A common $\mathrm{C}->\mathrm{T}$ polymorphism at nt 46 in the promoter region of coagulation factor XII is associated with decreased factor XII activity. Thromb Res 2001;101:255-260.

-16 Salazar LA, Hirata MH, Cavalli SA, Machado MO, Hirata RD: Optimized procedure DNA isolation from fresh and cryopreserved clotted human blood useful in clinical molecular testing. Clin Chem 1998;44:17481750.

17 Zito F, Drummond F, Bujac SR, Esnouf MP, Morrissey JH, Humphries SE, Miller GJ: Epidemiological and genetic association of activated factor XII concentration with factor VII activity, fibrinopeptide A concentration, and risk of coronary heart disease in men. Circulation 2000;102:2058-2062. 
18 Orth M, Westphal S, Dierkes J, Luley C, Schlatterer K: Rapid factor XII (46 C>T) genotyping by fluorescence resonance energy transfer in patients with coronary artery disease or thrombophilia. Clin Chem 2001;47: 1117-1119.

19 Colhoun H, Zito F, Chan N, Rubens M, Fuler J, Humphries S: Activated factor XII levels and factor XII 46C $>$ T genotype in relation to coronary artery calcification in patients with type I diabetes and healthy subjects. Atherosclerosis 2002;163:363-369.

-20 Kohler H, Futers T, Grant P: FXII $(46 \mathrm{C}>\mathrm{T})$ polymorphism and in vivo generation of FXII activity-gene frequencies and relationship in patients with coronary artery disease. Thromb Haemost 1999;81:745-747.

-21 Bach J, Endler G, Winkelmann BR, Boehm BO, Maerz W, Mannhalter C, Hellstern P: Coagulation factor XII (FXII) activity, activated FXII, distribution of FXII C46T gene polymorphism and coronary risk. J Thromb Haemost 2008;6:291-296.
22 Roldán V, Corral J, Marín F, Pineda J, Vicente V, González-Conejero R: Synergistic association between hypercholesterolemia and the C46T factor XII polymorphism for developing premature myocardial infarction. Thromb Haemost 2005;94:1294-1299.

23 Soria JM, Almasy L, Souto JC, Bacq D, Buil A, Faure A, Martínez-Marchán E, Mateo J, Borrell M, Stone W, Lathrop M, Fontcuberta J, Blangero J: A quantitative-trait locus in the human factor XII gene influences both plasma factor levels and susceptibility to thrombotic disease. Am J Hum Genet 2002;70:567574.

24 Cochery-Nouvellon E, Mercier E, LissaldeLavigne G, Daurès JP, Quéré I, Dauzat $M$, Marès P, Gris JC: Homozygosity for the C46T polymorphism of the F12 gene is a risk factor for venous thrombosis during the first pregnancy. J Thromb Haemost 2007;5:700707.

25 Reuner KH, Jenetzky E, Aleu A, Litfin F, Mellado P, Kloss M, Jüttler E, Grau AJ, Rickmann H, Patscheke H, Lichy C: Factor XII C46T gene polymorphism and the risk of cerebral venous thrombosis. Neurology 2008; 70:129-132.
26 Bach J, Endler G, Mannhalter C, Hellstern P: Coagulation factor XII (FXII) activity, activated factor XII, distribution of factor XII C46T gene polymorphism and coronary risk: reply to a rebuttal. J Thromb Haemost 2008;6:1055-1056.

27 Miller CH, Hooper C: Phenotypic and genotypic differences in factor XII between African Americans and Caucasians. J Thromb Haemost 2007;5:1981-1982.

28 Szolnoki Z: Evaluation of the interactions of common genetic mutations in stroke. Methods Mol Med 2005;104:241-250.

29 Kohler HP, Carter AM, Stickland MH, Grant PJ: Levels of activated FXII in survivors of myocardial infarction - Association with circulating risk factors and extent of coronary artery disease. Thromb Haemost 1998; 79:14-18.

30 Prusa R, Zadina J, Bronský J: Activated factor XII in patients with hyperglycaemia and dyslipidaemia. Vnitr Lek 2004;50:917-922. 